\title{
THE SUPREME COURT OF CANADA, THE HOUSE OF LORDS, THE JUDICIAL COMMITTEE OF THE PRIVY COUNCIL, AND ADMINISTRATIVE LAW
}

\author{
D. H. CLARK*
}

The Supreme Court of Canada's contribution to the jurisprudence of administrative law has been weak and fitful, erratic and lacking in attention to the principles of its own previous decisions. Failure to articulate points of distinction between its decisions has led to uncertainty in the law. The speaker suggested that the insufficiency of the Court's reasoning and the inadequacy of its citation might be reduced if judgments were more often delivered by more members of the Court, thus increasing the individual research and writing of the Court so that its earlier decisions would be kept in view and the case law developed more coherently. Furthermore, the Court should follow the House of Lords in not considering itself bound by its own decisions. The speaker regretted the Court's tendency to take a mechanically conceptualistic approach to substantive administrative law issues; if Canadian courts are to keep pace with those of other jurisdictions, the Supreme Court of Canada cannot continue to use outworn mumbo-jumbo as a substitute for identifying and grappling with the competing societal interests that are the stuff of administrative law.

The speaker also discussed and compared the contributions of the House of Lords and of the Judicial Committee of the Privy Council. Although it has fewer members, the House of Lords has more dissenters in administrative law decisions than the Supreme Court of Canada, (whereas the Privy Council until 1966 could not have a dissent). While the S.C.C. has been inconsistent and weak, the Privy Council has been consistent and weak. Although there have been occasional achievements, between 1951 and 1971 the Privy Council rendered a series of regressive decisions that impaired coherent development of the administrative law in England and in the Commonwealth.

On the other hand, the House of Lords, under the influence of the late Lord Reid, who did not sit on the regressive Privy Council decisions, since the early 1960's has enjoyed its most creative period in relation to public law. However, a balanced assessment of this Court's performance in this area must take into account that it too, like the S.C.C., has been unable to lay the foundations for an appropriate common law liability by the executive for unlawful administrative action.

The task, in addition to offering some comments on Professor Jones' paper, of venturing a comparative appraisal of the performance of the House of Lords and the Judicial Committee of the Privy Council vis-a-vis that of the Supreme Court of Canada in the administrative law field, was an alluring one for a commentator with an English background. Whether in its execution, in light of the conclusions reached, one has been able to avoid the trap of leaving ground for reasonable suspicion of bias, turns initially perhaps on Professor Jones' own assessment that Canada's ultimate Court of Appeal has fallen far short of the mark of administrative justice.

In evaluating the achievements of any particular court, an immediate temptation is to weigh in the balance the merits of the results reached in its individual decisions. Certainly scarcely any of the pronouncements of the Supreme Court of Canada in relation to public law has lacked substantive criticism. As a criterion for present purposes, however, such an approach is manifestly unsatisfactory, being subjectively based on the critic's own value judgments. Even if objective measurement were possible, it would be likely to

- Professor of Law, Dalhousie University. 
reveal only that, like all humans and human institutions, the Supreme Court has been right sometimes. ${ }^{1}$ Steering clear of such a touchstone Professor Jones used rather, in part, that of the degree to which the Court has adopted an interventionist approach. By inference from his observations on P. W. Hogg's stance, ${ }^{2}$ he feels that the Supreme Court has not been as expansionist as it might have been in wielding the tools of judicial review. (Parenthetically, my reading of Professor Hogg's thesis is not that the courts should not exercise supervision over statutory bodies, but that their control should be strategic rather than tactical.) Again, a large element of value judgment is here involved. On any view, however, one could hardly describe as restrained the Supreme Court's treatment hitherto of the decisions of Labour Relations Boards. It may be that Service Employees' International Union v. Nipawin District Staff Nurses Association ${ }^{8}$ presages a moderation of the Court's activism in this area, and at least a partial recognition that, as Lord Wilberforce acknowledged in Anisminic, Ltd. v. Foreign Compensation Commission:4

We have reached a stage in our administrative law when we can view that question [scil. that of the jurisdiction entrusted to a statutory tribunal] quite objectively without any necessary predisposition towards one that questions of law, or questions of construction, are necessarily for the courts.

If activism as an end of judicial review is antithetical to such objectivity in statutory construction, it is submitted that the same must be said for the converse. Judicial restraint, advocated by Hogg, seems to me to have value as an overriding objective only inasmuch as it means that a court on review should ascertain from the statute in question, without the predisposition alluded to by Lord Wilberforce, the extent of jurisdiction given to the administrative agency and respect the legislature's allocation of power (be it labelled law, fact or policy). The Supreme Court was extensively and rightly criticized for ignoring an explicit 'exclusive jurisdiction' clause in Metropolitan Life Insurance Co. v. International Union of Operating Engineers ${ }^{5}$ in relation to a matter of statutory construction. Yet it was surely no less in error in the deference it showed towards the agency's decision in R. v. Quebec Labour Relations Board, ex parte Komo Construction, ${ }^{6}$ in relation to a matter of preliminary procedure. There the applicant company impugned the Board's decision granting a union's petition on the ground that the petition had not been accompanied by, inter alia, a certified copy of the union's constitution and by-laws, a procedural requirement unequivocally imposed by the Quebec Labour Code. Without finding it necessary even to quote the relevant provisions of the Code Pigeon J., delivering the judgment of the Court, described the statute generally as being "addressed to the Labour Relations Board," and went on to say that the fundamental purpose of the Labour Code was:?

1 At the lower levels of the judicial hierarchy the frequency of successful appeals from a particular court or judge might, at either extreme, be considered significant. Such was the record of one English Chancery judge at the turn of the century that counsel is apocryphally said on one occasion to have thus begun his address to the Court of Appeal: "My Lords, this is an appeal from Kekewich J.; but there are other grounds."

2 See (1973) 11 Osgoode Hall L.J. 187.

8 (1974) 41 D.L.R. (3d) 6.

[1969] 1 A11 E.R. 208, at 246.

5 [1970] S.C.R. 425. The most trenchant critic was Professor Paul C. Weiler, who in The 'Slippery Slope' of Judicial Intervention, (1971) 9 Osgoode Hall L.J. 1, at 32, described the Court's reasoning as "pure nonsense".

6 (1969) 1 D.L.R. (3d) 125.

Id. at 126. 
... to confer exclusive $e^{8}$ jurisdiction upon the Board to deal with petitions for certification, and this implies that it is incumbent upon the Board to determine in each case whether the provisions of the Labour Code have been compiled with in this connection.

Concession to the Board in such general terms of an unreviewable authority to "deal with" petitions for certification free from any limit imposed by the concepts of jurisdictional fact or procedural precondition, exemplifies judicial restraint carried to the point of abdication of the judicial function. It is suggested that the legislative will would have been more respected had the Supreme Court examined the purpose of the statutory requirement that the specified documents be filed, assessed the prejudice (if any) causd by noncompliance, and determined accordingly whether the provision in question was to be treated as mandatory (failure to comply being invalidatory) or merely directory.

The most apposite criterion in evaluating the performance of a court of ultimate appeal, as applied to the Supreme Court of Canada in the field under consideration, is the degree of its effectiveness in using the relatively infrequent opportunities presented to it to develop the jurisprudence of administrative law. Unhappily but undeniably the Court's contribution has been weak and fitful. Professor Hogg's conclusion, quoted and endorsed by Professor Jones, that the court has steered an erratic course with ostensibly frequent oblivion regarding its own previous decisions and scant concern for the articulation of the principles and policies informing its decisions, is only too well borne out by the record. A classic example is to be found in the area of natural justice, where the Ridge v. Baldwin-like tenor of L'Alliance des Professeurs Catholiques de Montreal v. Labour Relations Board of Quebec in 1953 was followed six years later by the sterile conceptualism of Calgary Power Ltd. v. Copithorne.10 After only six more years the Supreme Court pendulum swung right back in the opposite direction with the decision in Wiswell v. Metropolitan Corporation of Greater Winnipeg. ${ }^{11}$ If it is remarkable that the Court was unanimous in all three cases as to the applicability or inapplicability of natural justice, ${ }^{12}$ more significant is the astounding absence of any reference in Calgary Power to the earlier decision and the lack of any reference in Wiswell to Calgary Power, with which it is exceedingly difficult to reconcile. ${ }^{13}$ In the latter case, of course, the Supreme Court put itself into voluntary bondage to the Judicial Committee of the Privy Council by espousing the ratio of Nakkuda Ali v. Jayaratne, ${ }^{14}$ a bondage that unfortunately still stunts its development of this area of the law, as evidenced by the judgment delivered by Pigeon J. for the majority of the Court in Howarth v. National Parole Board.15 It is pertinent to recall an earlier analogous volte face under external influence. In 1936 in Harris v. Law Society of Alberta ${ }^{10}$ the Supreme Court of Canada had an op-

8 The emphasis is that of Pigeon J.

${ }^{\circ}$ [1953] S.C.R. 140.

10 [1959] S.C.R. 24.

11 [1965] S.C.R. 512.

12 The result in Wiswell was dissented from by Judson J., who felt that on the facts the audi alteram partem principle had been satisfied.

1s In a recent examination a student of mine, with a felicitously evocative slip, of the pen particularly apt here, referred to the Supreme Court's "supervisory roll".

14 [1951] A.C. 66 .

15 (1975) 50 D.L.R. (3d) 349. The 'reception' of Nakkuda Ali has had its most baleful effect, however, in some provincial courts: a judge of the Saskatchewan Court of Queen's Bench described it in 1972 as "the leading English case" on natural justice (Davis J. in Re Crux and Leoville Union Hospital Board (No. 2) (1972) 32 D.L.R. (3d) 373 ).

16 [1936] S.C.R. 88. 
portunity to consider the circumstances in which economic loss directly caused by administrative illegality was compensable in damages. The action had been brought by a barrister and solicitor who some years earlier had been struck from the rolls in breach of the rules of natural justice, though in circumstances not constituting a breach of contract or a tort. At first instance damages had been awarded in addition to a declaration that the removal of the plaintiff's name from the rolls was invalid. When the matter reached the Supreme Court, it was held that whilst the declaration had been rightly granted there was no basis in law for an award of damages. Delivering the judgment of the Court Duff C.J.C. said ${ }^{17}$ that this aspect of the case "is governed by Partridge's case," decided by the English Court of Appeal in 1890.13 A dentist who had suffered a professional fate similar to Harris's, Partridge had failed in his claim for damages on the ground that in the absence of malice no liability lay in respect of loss suffered as a result of the ultra vires exercise of a 'judicial' function, broadly defined as any function involving any element of discretion. No mention was made in Harris of the Supreme Court's own decision in 1916 in McGillivray v. Kimber, ${ }^{19}$ where a river pilot dismissed without compliance with procedural formalities had recovered damages even though no allegation of malice had been made in the pleadings. The fullest of the majority judgments in that earlier case had been delivered by . . . Duff J.! Sixty years on, the issue of the proper scope for damages in administrative law remains still unresolved in Canada. ${ }^{20}$

Inattention by the Supreme Court to its own previous decisions is equally regrettable even in instances where consideration of an earlier case would probably not have changed the result in the later one. Failure to articulate the points of distinction leads to needless uncertainty, as may be illustrated by reference to the coexistence of Jarvis v. Associated Medical Services, Inc. ${ }^{21}$ and Galloway Lumber Co. v. The Labour Relations Board of B.C. ${ }^{22}$ concerning the thorny question of jurisdictional fact. None of the three judges in the latter decision who concluded that the impugned determination of the Labour Relations Board did not involve a "collateral" or "jurisdictional" question, made any reference whatever to the contrary decision in Jarvis where a similar challenge had succeeded. The omission is accentuated by the fact that the remaining two members of the Court, while concurring in the result on the facts, expressly considered the case on all fours with Jarvis on the jurisdictional issue. ${ }^{23}$ The cases are, I think, reconcilable; but why did not the 'majority' explain rather than merely state their conclusion? Juxtaposition of Metropolitan Life $(1970)^{24}$ and Pringle v. Fraser $(1972)^{25}$ prompts the same question. In the former, all nine members of the Supreme Court ruled that an exclusive jurisdiction clause in The Labour Relations Act of Ontario (which also contained, in a separate section, a traditional privative clause) did not preclude the Court from sub-

17 Id. at 93.

18 Partridge v. The General Council of Medical Education (1890) 25 Q.B.D. 90.

19 (1915) 52 S.C.R. 146.

$20 \mathrm{It}$ is unclear from Roncarelli v. Duplessis [1959] S.C.R. 121, on what juristic basis the award to the plaintiff of $\$ 33,000$ damages rested; semble, it was made under Art.1053 of the Quebec Civil Code (dealing with delict).

21 [1964] S.C.R. 497.

22 [1965] S.C.R. 222.

23 Perhaps at least a partial explanation is that Judson J., who delivered the 'majority' opinion in Galloway Lumber, had been in dissent on the jurisdictional issue in Jarvis.

24 [1970] S.C.R. 425.

25 (1972) 26 D.L.R. (3d) 28. 
stituting for that of the Board its own view on a question of statutory construction. Two years later the Court held with equal unanimity that a statutory provision creating an agency with "sole and exclusive jurisdiction to hear and determine all questions of fact or law, including questions of jurisdiction"26 displaced its inherent power of judicial review. Again, the decisions are probably reconcilable, but it is extraordinary that Metropolitan Life was not even referred to by Laskin J. in his judgment for the full court in Pringle v. Fraser. As a result of the Court's piecemeal approach a number of important questions as to the inter-relationship of the two cases, to which it is submitted it was the Supreme Court's duty to the legal profession and the public to address itself, are left open: was it part of the ratio in Pringle v. Fraser that there were other indicia in the Immigration legislation that the courts' supervisory powers were excluded - for example, the provision for an ultimate appeal to the Supreme Court? Was it material that the Immigration Appeal Board is itself an appellate body, whereas a Labour Relations Board is a tribunal of first instance? Is an exclusive jurisdiction clause conceptually distinct from the historically orthodox privative clause, and limited in its operation to questions of fact and statutory construction with no saving effect in respect of decisions otherwise ultra vires? In Pringle v. Fraser, it should be remembered, the appellant challenged a deportation order essentially on the ground that he had been denied a fair hearing prior to its making. Academics will get much mileage out of conjecture as to the current standing of Metropolitan Life, there being particular fascination for those with jurimetrical inclinations in comparing the now Chief Justice of Canada's judgment in the Ontario Court of Appeal in that case $^{27}$ with his pronouncement from the Supreme Court bench in Pringle v. Fraser. If a coherent system of administrative law is to be developed in this country, however, the highest court in the land will have to provide more than a series of staccato individual decisions which, however correct on their particular facts, fail to articulate their relationship to even their immediate predecessors. A positive recent achievement of the Supreme Court has been to clarify the muddied waters of locus standi, at least in relation to the matter of standing to challenge the constitutionality of legislation by an action for a declaration; the landmark decision in Thorson v. Attorney-General of Canada (No. 2) ${ }^{23}$ and its further extension in Nova Scotia Board of Censors et al. v. McNeil, ${ }^{20}$ admirably demonstrate the common law's capacity for evolution. Yet here again an unnecessary element of uncertainty has been created. Judson J. (with whom Fauteux C.J.C. and Abbott J. concurred) dissented in Thorson because he considered the case to be covered by the ratio of Smith v. A.-G. Ont., ${ }^{30}$ a long-standing Supreme Court decision. Although the majority purported to distinguish Smith it seems to be inconsistent with the reasoning in Thorson and plainly unable to stand with McNeil. In the lower courts the art of circumvention by distinction is a protection against the perpetuation of bad or out-dated law by stare decisis. Is there a need for the Supreme Court to practice such sophistry? Surely it is preferable to exorcize a ghost from the past like Smith rather than to pass by, leaving it to reappear at the behest of counsel to confound a future court.

Two practical suggestions are now offered that could go some way towards combatting the points of weakness that have been identified. Firstly, the insufficiency of the Supreme Court's reasoning and the inadequacy of its citation

${ }_{20}$ Immigration Act, R.S.C. 1970, c.I-2, s.22.

27 (1969) 2 D.L.R. (3d) 652.

28 (1974) 43 D.L.R. (3d) 1.

20 Judgment pronounced May 20,1975, unreported at the time of writing. [Since reported (1975) 5 N.R. 43]

30 [1924] S.C.R. 331. 
might be reduced if, instead of the normal practice of only one judgment being given for the whole Court (or in the case of a split decision one majority and one dissenting opinion), judgments were more often delivered by more members of the Court. Unlike Thomas Jefferson one is not here advocating that there should be as many individual reasoned opinions given as there are members of the bench, ${ }^{31}$ nor that as so often happens in the House of Lords there should be repetitious recitals of the facts and reviews of the applicable law. Nonetheless, the number of gyrations executed by the Supreme Court often within short periods of time with seeming unanimity, is unnatural. Prescription of more individual research and writing would be calculated to keep earlier decisions in view and contribute to a more coherent case-law. Secondly, the Supreme Court should come down off the fence, follow the precedent set by the House of Lords in $1966,{ }^{32}$ and state that it will no longer consider itself bound to follow its own previous decisions. This would both reduce voluntary amnesia and by removing the necessity for advances on occasion to be made obliquely would release the innate energies of the common law to respond appropriately to new pressures.

Neither of these steps, however, would be any antidote to another condition that periodically appears to afflict a majority of the Supreme Court of Canada: a tendency to take a mechanically conceptualistic approach to substantive administrative law issues. In Howarth v. National Parole Board ${ }^{33}$ the symptoms are plain. Like the directly analogous case that came before the United States

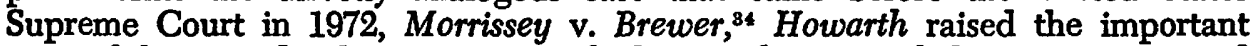
issue of the procedural protection to which a parolee is entitled on suspension and subsequent revocation of his parole. In the disposition of the issue by the respective courts there is no common ground whatever, but the comparison is illuminating. Summarizing the conclusions in Morrissey v. Brewer, Brennan J. stated that the parolee must be afforded: ${ }^{85}$

... first, a preliminary hearing at the time of arrest to determine whether there is probable cause to believe that he has violated his parole conditions and, second, a final hearing within a reasonable time to determine whether he has, in fact, violated those conditions and whether his parole should be revoked. For each ${ }^{36}$ hearing, the parolee is entitled to notice of the violations alleged against and the evidence against him, opportunity to be heard in person and to present witnesses and documentary evidence, and the right to confront and cross-examine adverse witnesses, unless it is found that the witness would thereby be exposed to a significant risk of harm. Moreover, in each case the decisionmaker must be impartial, there must be some record of the proceedings, and the decisionmaker's conclusions must be set forth in written form indicating both the evidence and the reasons relied upon.

In stark contrast, our own Supreme Court in Howarth sent away without remedy a parolee whose parole was first suspended and then revoked without his being given even a statement of the reason why or the most basic opportunity to make a case in his own defence. It is true that the Parole Act in Canada ${ }^{37}$ explicitly

81 As a means of smoking out the "Tazy or timid" judge, Jefferson favoured a rule requiring each judge to declare an opinion in each case, to "throw himself in every case on God and his country; both will excuse him for error and value him for his honesty." Jefferson's Works, vol. 7, p. 276.

82 See Practice Note, [1966] 3 A11 E.R. 77.

33 Supra, n. 15.

84 (1972) 92 S. Ct. 2593.

35 Id. at 2605. Brennan J. went further in holding the parolee entitled to counsel at each hearing, whilst Douglas $\mathrm{J}$. held that the fact of violation of parole must be established by a hearing before the parolee's arrest.

36 Emphasis added.

87 R.S.C. 1970 , c. P-2. 
provides $^{88}$ that the National Parole Board, in considering whether parole should be revoked, "is not required to grant a personal interview to the inmate or to any person on his behalf," but the Act does require the Board, in carrying out its review of any suspension of parole, to "cause to be conducted all such inquiries in connection therewith as it considers necessary." 39 This provision, enacted in 1970, enabled a minority of the Court to distinguish an earlier Supreme Court decision ${ }^{40}$ denying any right to a hearing before parole is finally revoked. For the majority, however, it was not material to the narrow initial question to be resolved on Howarth's application to the Federal Court of Appeal under s. 28 of the Federal Court Act ${ }^{41}$ to review and set aside the decision made against him in alleged breach of natural justice. That question was whether the Parole Board's decision was one "of an administrative nature not required by law to be made on a judicial or quasi-judicial basis." If it was such a decision, the Federal Court of Appeal, by s. 28(1), had no jurisdiction in the matter. No artificial constraint of this kind had shackled the United States Supreme Court in the Morrissey case, but the tenor of the judgments makes it inconceivable that in similar circumstances it would have displayed the unimaginative conservatism that rendered its Canadian counterpart a willing prisoner of a poorly drafted statutory provision delimiting the supervisory jurisdiction over federal tribunals. By treating the double negative in s. $28(1)$ as entrenching the now outdated polarization between administrative and judicial functions, the latter exclusively being susceptible to the principles of natural justice, the majority of the Court turned their back on the principle pioneered and now well recognized in England that the exercise of an administrative function must be preceded by an impartial hearing in circumstances where fairness demands it. ${ }^{42}$ Dickson J.'s minority opinion shows how easily the clumsy wording of s. 28 (1) can be read as embracing this development. One ought to mention that Pigeon J. did faintly suggest that some administrative functions might be reviewable in the Trial Division for breach of a "duty to act fairly."13 It is unlikely, though, that the learned judge intended duty to have any procedural connotation; ${ }^{44}$ subsequently, in delivering the Court's judgment in Saulnier v. Quebec Police Commission and Montreal Urban Community,"s untrammelled by the Federal Court Act, he held that natural justice was applicable to certain functions exercised by the Quebec Police Commission because they were of a quasi-judicial and not, as had been held by the Quebec Court of Appeal, of an administrative nature.

It was contended earlier that the majority in Howarth were willing prisoners of the statute. In reality the decision owed less to statutory constriction of the

88 s.11.

${ }^{89} \mathrm{s.16}(4)$. The Iowa parole statute that provided the legislative backcloth in Morrissey v. Brewer was totally silent as to revocation procedure.

10 Ex p. McCaud [1965] 1 C.C.C. 168, aff'd. [1965] I C.C.C. 170n.

41 R.S.C. 1970 , c. 10 (2nd Supp.).

42 See, for example, In re H. K. (an infant) [1967] 2 Q.B. 617 (C.A.); R. v. Gaming Board for Great Britain, ex parte Benaim and Khaida [1970] 2 Q.B. 417 (C.A.); Maxwell v. Department of Trade and Industry [1947] Q.B. 523 (C.A.).

4 Supra, n. 15 , at 353 .

«If he did, I share Professor David Mullan's horror at the prospect of the courts becoming "involved-not in a one-stage classification process but in a two-stage onejudicial and quasi-judicial functions to which natural justice applies, then, within administrative functions, quasi-administrative functions where procedural fairness applies, and then purely administrative functions where neither natural justice nor procedural fairness applies." Fairness: The New Natural Justice?, in Current Issues in Administrative Law (Dalhousie Continuing Legal Education Series, No. 7) at 8.

15 Judgment pronounced February 13, 1975; unreported at the time of writing. 
Court's frame of reference than to a barren conceptualism that gave no sign of any awarness of the social context in which the case arose and upon which the decision would undoubtedly have a marked effect. Calgary Power Ltd. v. Copithorne $^{46}$ was cited to establish the negative that the duty to act judicially did not arise whenever private rights were affected, and Lord Hewart C.J.'s gloss on Atkin L.J.'s hackneyed dictum in R. v. Electricity Commissioners ${ }^{4}$ was dusted off to show that the duty exists only where it is (in some unspecified way) "superadded" to legal authority to take action affecting individuals" rights. Compare such aridity to the approach taken in Morrissey v. Brevver. There the United States Supreme Court began by analyzing the function of parole in the correctional process, turned then to the nature of the interest of the parolee in his continued liberty (recognizing that "it is hardly useful any longer to try to deal with this problem in terms of whether the parolee's liberty is a right or a privilege" ${ }^{48}$ ) and finally made the following telling observations: ${ }^{49}$

The parolee is not the only one who has a stake in his conditional liberty. Society has a stake in whatever may be the chance of restoring him to normal and useful life within the law. Society thus has an interest in not having parole revoked because of an erroneous evaluation of the need to revoke parole, given the breach of parole conditions.50 ... Society has a further interest in treating the parolee with basic fairness: fair treatment in parole revocations will enhance the chance of rehabilitation by avoiding reactions to arbitrariness.

Anyone who has visited penitentiary inmates and felt the bitterness caused by unreasoned refusal and revocation of parole will appreciate the force of this societal interest. In the evaluation of competing interests that is the stuff of administrative law, there will always be those to criticize any decision as not striking the "right" balance. But if the Canadian Courts are to keep pace with those of other jurisdictions in the regulation of administrative power (let alone strike out in novel directions, as Professor Jones would wish) the Supreme Court cannot go on using outworn mumbo-jumbo as a substitute for identifying and grappling with those interests.

After paying tribute in such base coinage to the institution whose centenary we now celebrate, let me turn to the second part of my commission, and to two courts whose formal title of committee is suggestive of a more distant origin in English constitutional history.

\section{The Judicial Committee of the Privy Council and The House of Lords ${ }^{51}$}

Administrative law cases constitute a very small part of both courts' workloads. Whilst the Supreme Court of Canada itself has on average only three to four such cases per year, ${ }^{52}$ a recent study ${ }^{53}$ reveals that House of Lords decisions

46 Supra, n. 10.

47 [1923] All E.R. Rep. 150.

18 Supra, n. 34, at 2601.

49 Id. at 2602.

50 Id. Even the minority in Howarth saw the parolee's right to be heard as limited to the factual determination of whether parole conditions had been violated: supra, n. 15 , at $361-2$.

51 As a court comprising professional judges the House of Lords has not yet reached its century; at the time when the Supreme Court of Canada was born the English upper chamber as a judicial body was under sentence of death, imposed when the Judicature Bill introduced in 1872 received the Royal Assent the following year. Execution, set for November 1874, was first suspended and then rescinded with the enactment of the Appellate Jurisdiction Act 1876. The reconstituted House of Lords heard its first appeals in 1877.

62 See P. W. Hogg, (1973) 11 Osgoode Hall L.J. 187, at 191.

${ }^{53}$ L. Blom-Cooper, Q.C. and G. Drewry, Final Appeal. Clarendon Press, Oxford, 1972. 
in the whole field of public law (i.e. constitutional as well as administrative law) for the period 1952 - 1968 numbered a mere twenty-five, an annual average of less than 1.5. For the Privy Council the average falls below one such case per year. These figures have not shown any increase more recently. Reported administrative law decisions in the three and one half years from the beginning of 1972 up to the time of writing number, in the House of Lords, two; ${ }^{54}$ in the Privy Council, one. ${ }^{.5}$ A further similarity between the two courts lies in their personnel. The nuclear element of the Judicial Committee of the Privy Council comprises Lords of Appeal in Ordinary, although senior Commonwealth judges, active and retired, are increasingly being utilized (usually one at a time). In contrast to the norm for the Supreme Court of Canada of a nine-member (full) court, in the House of Lords almost invariably five members chosen by the Lord Chancellor normally from the eleven Lords of Appeal in Ordinary, constitute the Appellate Committee. The Privy Council, too, often sits as a fivemember court. However, an unfortunate vestige of a colonial caste system survives in that while a five-member court is convened for appeals from independent Commonwealth countries, dependent countries (save in exceptional cases considered particularly complex or important) rate only a three-member court.

Notwithstanding the disparity in the size of their respective working memberships the House of Lords has more dissenters in administrative law cases than does the Supreme Court of Canada. Some of the latter's 9-0 decisions referred to earlier would almost certainly not have been unanimous in the House of Lords. Among recent landmark decisions, for example, Ridge v. Baldwin, ${ }^{56}$ Anisminic, Ltd. v. F.C.C. ${ }^{57}$ and Padfield v. Minister of Agriculture, Fisheries and Food ${ }^{58}$ all divided the Law Lords, the former two being in fact overall minority decisions in that of the nine judges in the three courts that heard each of the cases only four were in favour of the final outcome. In the Privy Council until recently no dissent was permissible, the constitutional theory being that all the members of a committee charged with tendering humble advice to the Sovereign must tell the same story. This must have had the consequence that the court's reported judgment in some instances represented no more than the highest common factor of agreement. Occasionally the internal evidence of the accommodation of different views is particularly strong. Lord Sumner's apparent equivocation concerning 'no evidence' as a ground for judicial review, in what Professor Jones has dubbed the "notorious" R. v. Nat Bell Liquors, Ltd., ${ }^{59}$ is submitted to be explicable on this basis. By Order in Council in 1966, ${ }^{\circ 0}$ however, allowance was made for a dissenting as well as a majority opinion to be

54 R. v. Lewes JJ., ex parte Secretary of State for Home Dept., [1972] 2 A11 E.R. 1057; Hoffman-LaRoche v. Secretary of State for Trade and Industry [1974] 2 A11 E.R. 1128.

35 Furnell v. Whangarei High Schools Board [1973]1 All E.R. 400.

86 [1964] A.C. 40.

67 [1969] 1 A11 E.R. 208.

58 [1968] A.C. 997.

59 [1922] A.C. 128.

60 The Judicial Committee (Dissenting Opinions) Order 1966. 
delivered in the Judicial Committee, and indeed its latest administrative law decision, Furnell v. Whangerei High Schools Board, divided the court 3:2.61

Remarkably for two courts with a largely overlapping membership, the respective contributions of the Privy Council and the House of Lords to the evolution of administrative law differ significantly in quality on an overall assessment. The former, unlike the Supreme Court of Canada, has in my view been consistent, but consistently weak. Certainly there have been spasmodic distinctive achievements: the best example is probably Robinson v. State of South Australia (No. 2) ${ }^{62}$ in 1931, which in the area of Crown privilege put most of the Commonwealth (Canada vacillating ${ }^{68}$ ) nearly forty years ahead of England, since not until 1967 with Conway v. Rimmeros did the House of Lords throw off the dead hand of Duncan v. Cammell, Laird. ${ }^{\circ 5}$ Then in 1963, by its interlocutory decision in David v. Abdul Cader, ${ }^{60}$ the Privy Council kept alive the possibility that the dormant tort of misfeasance in public office might be developed into a more general vehicle for compensating those suffering economic loss as a direct result of ultra vires acts and decisions. Furthermore the court's record in relation to appeals from Canada in administrative law matters is far from being the roll call of disaster that according to one school of thought represented its ventures into the constitutional field. $R$. v. Nat Bell Liquors ${ }^{87}$ has proved ambivalent enough to allow Canadian courts to assert, albeit timidly and without any real consistency, ${ }^{68}$ a common law power to review tribunals' findings of fact; White v. Kuzyck, ${ }^{09}$ concerning exhaustion of administrative remedies, is unexceptionable; and in the Wheat Board case, ${ }^{70}$ the Privy Council's analysis as an exercise in contextual statutory construction impresses me much more than that of the Supreme Court of Canada ${ }^{71}$ (Rand J.'s judgment excepted).

In the years 1951-1971, however, a series of regressive decisions was perpetrated in Whitehall that has impaired coherent development in England and around the Commonwealth. It is a sorry catalogue, beginning with Nakkuda

61 [1973] A.C.660. The closeness of the division in Furnell is particularly significant as the Privy Council was there face to face with what is proving for each of the three courts here under examination to be one of the most difficult issues in current administrative law: the determination of the relationship between the common law principle of natural justice and the increasing number of express statutory procedural provisions applicable to the proceedings of specific agencies. Equal unease is reflected in the House of Lords' narrow majority decision in Malloch v. Aberdeen Corp. [1971] 2 All E.R. 1278, where as in Furnell the scope of the audi alteram partem rule was in question, whilst in Law Soc. of Upper Canada v. French (1975) 49 D.L.R. (3d) 1, there was a marked divergence of opinion in the Supreme Court of Canada as to the effect of the Law Society Act of Ontario (now R.S.O. 1970, c. 238) on the common law rule against bias.

62 [1931] A.C. 704.

63 See, for example, Murray v. Murray [1947] 3 D.L.R. 141; R. v. Snider [1954] 1 S.C.R. 479; Reese v. R. [1955] Ex.C.R. 187.

64 [1968] A.C. 910.

65 [1942] A.C. 624.

66 [1963] 3 A11 E.R. 579.

67 Supra, n. 59.

${ }^{88}$ See D. W. Elliott, 'No Evidence': A ground of Review in Canadian Administrative Law? (1972-73) 37 Sask. Law Rev. 48.

60 [1951] A.C. 585.

${ }^{70}$ Nolan v. Hallett \& Carey Ltd. and Attorney-General of Canada (1952) 6 W.W.R. (N.S.) 23.

71 [1951] S.C.R. 81. 
Ali v. Jayaratne, ${ }^{72}$ whose continued attraction a quarter of a century later for Canadian courts up to the highest level has already been observed. ${ }^{78}$ University of Ceylon v. Fernando ${ }^{74}$ (1960) eviscerated the audi alteram partem principle by denying that due process at an oral hearing held by a disciplinary tribunal included the right to confront and cross-examine the key 'prosecution' witness on whose credibility the whole case was conceded to turn. More recently this decision has become incorporated by reference into English municipal law as part of the rationale for a refusal to recognize even a qualified right to legal representation as a facet of natural justice. ${ }^{75}$ In 1964 in Vidyodaya University of Ceylon v. Silva, ${ }^{78}$ a Privy Council including two Law Lords who in that other capacity had delivered majority judgments in Ridge v. Baldwin ${ }^{77}$ only months previously, incongruously ruled that no fair hearing was required before valid dismissal of a university lecturer statutorily dismissible only for cause. The reasoning in the case has now been subjected to criticism in the House of Lords. $^{78}$ Then in 1967 the advice given to Her Majesty in Durayappah v. Fernando $0^{7 \theta}$ was based on such confusion between the concept of locus standi and the supposed distinction between void and voidable decisions that it took Professor H. W. R. Wade 47 pages in the Law Quarterly Review to unscramble the separate issues..$^{80}$ Rationalization of the inter-relationship between public law remedies received a setback in Jayawardane v. Silva, ${ }^{81}$ in which the court, ignoring completely the recent broadening in England of the scope of certior$a^{i^{82}}$ and applying a formalistic definition of a judicial function, rejected in limine the applicant's claim for the prerogative order while hinting strongly that an action for a declaration would have succeeded. ${ }^{83}$ These cases have two things in common: firstly, they were all appeals from Ceylon. Predictably that country, on achieving independence as Sri Lanka, moved quickly to abolish the right of appeal to the Privy Council, with effect from the end of 1971. Secondly, Lord Reid did not sit to hear any of them.

Unlike the previous one this is not, I would suggest, a fortuitous statistic, for there is evidence that it is in large measure his influence in the Appellate Committee of the House of Lords that has led that court to enjoy since the early

72 [1951] A.C. 68.

78 Nevertheless it should not be forgotten that it was Nakkuda Ali that restored an objective construction to the if $\mathrm{X}$ has reasonable grounds to believe ... type of formula qualifying administrative discretion, which in Liversidge v. Anderson [1942] A.C. 206 had been interpreted by the majority in the House of Lords as meaning no more than 'if $\mathrm{X}$ thinks he has reasonable grounds to believe'.

74 [1960] 1 W.L.R. 223.

78 See Pett v. Greyhound Racing Association, Ltd. (No. 2) [1969] 2 W.L.R. 1228.

76 [1964] 3 A11 E.R. 865.

77 Supra, n. 56.

78 By Lord Wilberforce in Malloch v. Aberdeen Corporation [1971] 2 A11 E.R. 1278, at $1295 \mathrm{c}-\mathrm{f}$. Interestingly, in Malloch there were dissents from the two judges referred to in the text, Lords Morris and Guest.

79 [1967] 2 A11 E.R. 337. Durayappah was recently described in the House of Lords, somewhat charitably, as a "puzzling case": per Lord Wilberforce in Hoffman-LaRoche v. Secretary of State for trade and Industry [1974] 2 All E.R. 1128, at 1147.

80 See H. W. R. Wade, Unlawful Administrative Action: Void or VoidableP (1867) 83 L.Q.R. 499; (1968) 84 L.Q.R. 95.

81 [1970] 1 W.L.R. 1365.

82 See R. v. Criminal Injuries Compensation Board, ex parte Lain [1967] 3 W.L.R. 348.

83 The English Divisional Court, paying no heed to the Jayawardane case, has now carried still further its liberalization of certiorari from its historical confines: $R$. v. Hillingdon Borough Council, ex parte Royco Homes Ltd. [1974] 2 W.L.R. 805. 
1960's perhaps its most creative period in relation to public law. Until 1973 Lord Reid (whose lucid, simply constructed judgments embodying an instictive 'feel' for the essence of administrative justice bear a similarity to those of Rand $\mathrm{J}^{84}$ ) sat in only one major administrative law case in the Privy Council after White v. Kuzyck ${ }^{85}$ in 1951; that was Maradana Mosque (Board of Trustees) v. Badi-ud-din Mahmud, ${ }^{86}$ the source of the "asking the wrong question" jurisdictional test later adopted by the House of Lords in Anisminic and used (out of context) by the Supreme Court of Canada in Metropolitan Life. But coming into the House of Lords in 1948, the year after that court's decision in Franklin v. Minister of Town and Country Planning 87 had caused Professor Wade to fear for the very survival of natural justice, ${ }^{88}$ Lord Reid not merely sat to hear virtually every administrative law appeal coming before their Lordships' House until his death in office earlier this year, but after becoming the senior and presiding Law Lord in 1962 on the death of the conservative Viscount Simonds he delivered the leading judgment in most of them. Yet throughout this active span of twenty-seven years, apart from one dissent in 1965, Lord Reid never failed to carry with him a majority of his colleagues in an administrative law appeal. The sole exception was Smith v. East Elloe R.D.C. ${ }^{80}$ where it was held by the majority that a privative clause was effective to preclude judicial review even on the ground of bad faith. However, with the vindication in Anisminic, Ltd. v. F.C.C. ${ }^{\text {o0 }}$ of what had been the minority position in Smith came one of the House of Lords' most conspicuous achievements, a broad restatement of the ambit of the courts' supervisory jurisdiction in the face of both the traditional type of privative clause and subjectively formulated administrative powers.

In addition the last fifteen years has seen the declaration fully recognized as the leading public law remedy (Pyx Granite Co. Ltd. v. Minister of Housing and Local Government; ${ }^{21}$ Anisminic); the renaissance of natural justice (Ridge v. Baldwin ${ }^{02}$ ), currently undergoing a metamorphosis into a more pervasive concept of 'fairness' (Pearlberg v. Varty ${ }^{03}$ ); the further structuring of administrative discretion (Padfield v. Minister of Agriculture ${ }^{04}$ ) and the authoritative reassertion of the judiciary's final authority regarding claims of Crown privilege (Conway v. Rimmer, the first of two occasions on which the House of Lords

84 Compare, for example, their opinions in Ridge v. Baldwin and L'Alliance des Professeurs Catholiques de Montreal v. Quebec Labour Relations Board, respectively, and in Padfield v. Minister of Agriculture and Smith \& Rhuland Ltd. v. The Queen [1953] 2 S.C.R. 95.

${ }^{85}$ [1951] A.C. 585.

${ }^{86}$ [1967] A.C. 13 (also an appeal from Ceylon).

87 [1948] A.C. 87.

88 "The Stevenage case represents a sharp check to the development of judicial control of policy decisions which has been established by degrees over many years. . . . How long 'natural justice' will survive must for the time being remain an open question": (1949) $10 \mathrm{Camb}$. L.J. 216, at 240.

80 [1956] A.C. 736.

${ }^{80}$ [1969] 2 A.C. 147.

91 [1960] A.C. 260.

92 Supra, n. 56.

จ3 [1972] I W.L.R. 534.

94 Supra, n. 58. 
has actually ordered production of documents over ministerial objections ${ }^{95}$ ). Reference has already been made to Anisminic v. F.C.C., but its full impact may, it now appears, be even greater than has yet been appreciated. Certainly it is manifest that a court could at any time call Anisminic in aid in holding that particular error of law went to jurisdiction. It was after all this apprehension that led Lord Morris to dissent from the majority view. But in a speech in Cambridge in 1974 in honour of the late Professor S. A. de Smith, Lord Diplock gave a more radical interpretation of the decision: ${ }^{96}$

The House of Lords, reversing a timorous Court of Appeal [which, of course, included Diplock L.J.], held that in asking itself the wrong question in the case before it, as every tribunal must inevitably do if it makes any mistake as to the law applicable to the facts, the F.C.C. acted outside its jurisdiction. . . The wider significance of [Anisminic] is that it renders obsolete the technical distinction between errors of law which go to jurisdiction' and errors of law which do not. In doing so it enlarges the material that can be made available to the court on certiorari to found an inference that those responsible for an administrative decision have erred in law. So technicalities as to what constitutes the 'record' for the purposes of review no longer matter.

A broadening of the courts' common law supervisory jurisdiction to include latent errors of law would remove an historical anomaly, and would give general effect to the substance of a statutory reform made in Canada in 1970 and itself anomalously limited in application to review by the Federal Court of Appeal.97 Caution is required, however, both in inferring from Anisminic so sweeping a change and in welcoming it without qualification. The ratio of the decision, first of all, would appear not to extend to all errors of law but only those resulting from misconstruction of the terms of a statute or piece of delegated legislation. Whilst the error alleged in review proceedings may normally be of this nature, it will not be such in all cases; it is submitted, for example, that an agency's admission of inadmissible evidence (or the converse) continues at common law to be reviewable only if the error is disclosed by the record. It is indeed difficult to see any justification for debarring the court from itself admitting extrinsic evidence to establish that the agency has erred in this way. But whatever the force of the argument ${ }^{28}$ that it follows from first principles that whenever a tribunal of limited jurisdiction errs in law it thereby steps outside its jurisdiction, so that the concept of error of law within jurisdiction is an absurdity, by a strange paradox its abandonment would knock away the basis on which today the maintenance of the courts' power of jurisdictional review largely rests. Repeatedly and authoritatively ${ }^{09}$ it has been held that the ubiquitous ouster clauses

85 Supra, n. 64. See also Norwich Pharmacal Co. v. Comrs. of Customs \& Excise [1973] 2 Al1 E.R. 943, where the change in the temper of the court since its capitulation to the executive in Duncan v. Cammell Laird [1942] A.C. 624 may be gauged from its unanimity in overriding a claim for secrecy nothwithstanding the conclusion of Lord Denning M.R. (no less) in the Court of Appeal that "If there was ever a case in which it was in the public interest to ensure candour [by acceding to the Crown's objection to production], it is this very case": [1972] 3 All E.R. 813, at 818h-819a. In Alfred Crompton Amusement Machines Ltd. v. Comrs. of Customs \& Excise (No. 2)

[1973] 2 All E.R. 1169, however, the House of Lords unanimously upheld a claim to privilege made by the respondent, the claim having been overridden both at first instance and by the Court of Appeal.

${ }^{\circ}$ Administrative Law: Judicial Review Revisited, [1974] Camb. L.J. 233, at 243.

07 The Federal Court Act, R.S.C. 1970, c. 10, s. 28(1) empowers that division of the Court to review and set aside certain decisions or orders of federal administrative agencies on the ground, inter alia, that the agency "(b) erred in law in making its decision or order, whether or not the error appears on the face of the record."

98 Forcefully made, for example, by B. C. Gould in 'Anisminic' and Jurisdictional Review, [1970] Public Law 358.

${ }^{99}$ See, for example, Toronto Newspaper Guild v. Globe Printing Co. [1953] 2 S.C.R. 18. 
purportedly effecting a comprehensive statutory preclusion of judicial intervention have no effect in relation to any defect or error going to jurisdiction, the intention imputed to the legislators being solely that of preventing review of intra vires decisions for patent error of law. Though a fiction this is at least a theoretical possibility; once it is admitted that there are no such things as intrajurisdictional errors of law the courts' cover for remaining in the field has as much credibility as the emperor's new clothes. ${ }^{100}$

Vigorous as has been the House of Lords' substantive development over the last decade or so of what in France would be termed the principle of légalité a balanced assessment of the court's performance in the administrative law field must take account of the fact that, like the Supreme Court of Canada, it has proved quite unable even to lay the foundations for a common law counterpart to the twin principle of responsabilite in droit administratif whereby the administration is liable to make compensation for loss caused by unlawful administrative action. The issue was raised in a novel way in 1974 in Hoffman-LaRoche v. Secretary of State for Trade and Industry. ${ }^{101}$ By a statutory instrument made by the respondent following a report of the Monopolies Commission, the appellant drug manufacturer had been ordered to reduce the prices of two of its products (the tranquillizers Librium and Valium) by $60 \%$ and $75 \%$ respectively. The appellant having commenced an action seeking a declaration that the order was invalid as being substantively and procedurally ultra vires, the respondent sought an interlocutory injunction restraining the company, pending trial of the action, from charging prices for the named drugs in excess of those set out in the impugned order. On this appeal the question for the House of Lords was whether the trial judge had correctly exercised his discretion in attaching to the interim injunction the condition that the Crown should give an undertaking in damages (almost invariably required before such interim relief is granted to a private litigant), to protect the company against the loss which it would otherwise suffer through compliance with the injunction if its challenge to the validity of the respondent's order should ultimately be 'successful. Evidence was given to the effect that the sum involved was $£ 8$ million. Furthermore, since the Crown itself purchased for use in the National Health Service $90 \%$ of the Librium and Valium sold in the United Kingdom, it stood to benefit proportionately if granted an injunction enforcing an order subsequently held invalid. Yet it was held that no undertaking in damages should be required from the Crown in the instant case; the appellant must, in Lord Denning's graphic phrase in the Court of Appeal, "obey first and argue afterwards"10:2 even though the assumption was made that should it ultimately win the argument it would have at best a moral claim for an ex gratia payment. ${ }^{103}$ At the same time, however, it was expressly recog-

100 It is pertinent to recall the reasoning on which Judson J. concluded that full effect should have been given to the privative clause encountered in Jarvis v. Associated Medical Services, Inc. [1964] S.C.R. 497, at 510: "If the Legislature takes away the remedy of certiorari, it must be dealing with this so-called jurisdictional error, for the correction of jurisdictional error is the only purpose of certiorari."

101 Supra, n. 54.

102 [1973] 3 A11 E.R. 945, at 953.

103 As an alternative solution the company had offered, if the interim injunction were refused, to give an undertaking that while continuing to charge the full market price for the goods pending the outcome of the trial, it would deposit in a bank account in the joint names of the parties' solicitors a sum sufficient to enable full repayment to be made of all charges in excess of those specified in the ministry's order in the event of the latter's validity being upheld. This scheme received short shrift, Lord Reid expressing the basic objection to it as being that it would mean that "the law laid down in the order is to be disregarded until the case is decided": Supra, n. 54, at 1135a. 
nized that if the impugned statutory instrument were subsequently held to be ultra vires, the effect would be "to render the instrument incapable of ever having had any legal effect on the rights or duties of the parties to the proceedings." 104 In viewing it as being just and equitable in these circumstances to grant an interim injunction without protective terms, ${ }^{105}$ on the ground that the Crown was here seeking the enforcement of 'the law' in the form of an instrument that was not patently invalid, the House of Lords betrays the impoverished state of remedial administrative justice in England. Lord Wilberforce in a cogent but lone dissent identified an underlying: ${ }^{105 a}$

... unwillingness to accept that a subject should be indemnified for loss sustained by invalid administrative action. It is this which requires examination rather than some supposed visible quality of the order itself. In more developed legal systems this particular difficulty does not arise. Such systems give indemnity to persons injured by illegal acts of the administration.

Further evidence of how undeveloped English law is in this respect in comparison with the droit administratif created by the French Conseil d'Etat, is provided by another recent decision of the House of Lords: Home Office v. Dorset Yacht Company. ${ }^{106}$ A group of youths from an 'open' Borstal institution had escaped from the custody of their supervisors while on a training exercise on an island in a south-coast harbour, and in the process caused considerable damage to a yacht belonging to the respondent. By a majority the court rejected the Home Office's claim to total immunity from liability, holding on a preliminary issue of law that the Crown would be liable if negligence on the part of the Borstal officers could be established. So far as it goes the decision is to be welcomed. But surely the private law of tort is altogether too restrictive and inadequate to constitute the sole basis upon which to determine who should bear loss flowing directly from the carrying out in the public interest of governmental activities so different in kind from the private relations regulated by the law of negligence according to the principle of fault. The judge-made administrative law developed by the Conseil d'Etat in France has for long recognized the need for special principles of administrative liability, ${ }^{107}$ and the guiding notion of l'égalité devant les charges publiques has enabled it, in the words of one learned commentator, to "adapt an appropriate liability to the constantly changing demands of society."108 Appealingly simple in its essence, that principle is that if in the course of an administrative activity being carried out for the general good (however desirable and however carefully conducted) a disproportionate burden falls on an individual, equity requires that the cost should be equally shared. Thus in two cases very close on their material facts to Dorset Yacht, the Conseil d'Etat made express findings of no fault whilst holding the administration liable to make good the losses resulting from burglaries committed by absconders from penal institutions. ${ }^{109}$

104 Per Lord Diplock at 1154 a-b.

${ }^{105}$ The jurisdiction of English courts to grant an interim injunction arises, by the Supreme Court of Judicature (Consolidation) Act 1925, s. 45, "in all cases in which it appears to the court to be just or convenient to do so," and the relief may be granted on such terms or conditions as the court thinks fit.

105a Supra, n. 54, at 1148.

${ }^{106}$ [1970] 2 Al1 E.R. 294.

${ }^{107}$ For a good general outline see Brown and Garner, French Administrative Law (2nd. ed., 1973), ch. 8. The authors also give a useful bibliography of specialist writings in French and English.

108 Professor C. J. Hamson, (1969) 27 Camb. L.J. at 283.

100 Thouzellier, C.E. 3 February 1956, Rec. 49; Trouillet, C.E. 9 March 1966, Rec. 201. 
Returning finally and briefly to the Supreme Court of Canada, it is a matter for regret that although it stands at the apex of a judicial system which includes a civil law jurisdiction, it cannot draw from Quebec law (because the latter has not been infused with) the still-developing concept of administrative liability that is one of the greatest achievements of droit administratif. Instead, in Wellbridge Holdings Ltd. v. Metropolitan Corp. of Greater Winnipeg, ${ }^{110}$ like the House of Lords in the Dorset Yacht case, the Court was constrained by the pleadings and the argument presented to it to look only to the tort of negligence. The plaintiff, having leased certain lands for the purpose of building thereon a multistorey apartment building, applied for and obtained from the defendant a building permit on the basis that the land was zoned for such development. When construction was already underway the zoning by-law in question was held invalid, in proceedings inter alios. ${ }^{111}$ The plaintiff's building permit was immediately revoked and work on the apartment project came to a halt. It appears that the developer could be said to have taken a calculated risk, since at the time of his application for a permit the writ impugning the zoning by-law had already been issued; the plaintiff certainly was well aware of this fact, since a permit was initially refused on this very ground. Nevertheless, the circumstance was not material to the Supreme Court's ratio in roundly rejecting the claim for damages. Although one judge in the Manitoba Court of Appeal ${ }^{112}$ had felt able to bring the case within the Hedley Byrne principle, Laskin J., delivering the judgment of the unanimous Supreme Court, held conclusive against the defendant's liability the fact that it had throughout been acting in "its public character, involving its political and social responsibility to all those who live and work within its territorial limits." 11 It would, he went on, be "incredible" if a public authority should be liable to compensate an individual for loss incurred as a direct result of the exercise of such functions in good faith. It is respectfully submitted that such a notion can be considered incredible only within an inflexible framework in which liability is based on fault alone.

Are both the Supreme Court of Canada and the House of Lords, for all their achievements in refining the principle of administrative legality and in surmounting both self-imposed and statutory obstacles in the way of judicial review, too enmeshed in private law ways of thought to be capable of evolving appropriate principles of administrative liability? Will it take the institution of a specialist administrative jursdiction to discern for public authorities a broader "social responsibility"?

110 [1971] S.C.R. 957.

111 The decision was ultimately upheld by the Supreme Court of Canada in Wiswell et al. v. Metropolitan Corp. of Greater Winnipeg [1965] S.C.R. 512.

112 Freedman J.A. (see (1970) 12 D.L.R. (3d) 124).

118 Supra, n. 110, at 868. 